\title{
Is There a Constitutional Right to Clone?
}

\section{Citation}

Cass R. Sunstein, Is There a Constitutional Right to Clone? (Public Law \& Legal Theory Working Papers No. 22, 2002).

\section{Published Version}

http://chicagounbound.uchicago.edu/public_law_and_legal_theory/168/

\section{Permanent link}

http://nrs.harvard.edu/urn-3:HUL.InstRepos:12921750

\section{Terms of Use}

This article was downloaded from Harvard University's DASH repository, and is made available under the terms and conditions applicable to Other Posted Material, as set forth at http:// nrs.harvard.edu/urn-3:HUL.InstRepos:dash.current.terms-of-use\#LAA

\section{Share Your Story}

The Harvard community has made this article openly available.

Please share how this access benefits you. Submit a story.

\section{Accessibility}




\section{University of Chicago Law School Chicago Unbound}

Public Law and Legal Theory Working Papers

Working Papers

2002

\section{Is There a Constitutional Right to Clone?}

Cass R. Sunstein

Follow this and additional works at: http://chicagounbound.uchicago.edu/ public_law_and_legal_theory

Part of the Law Commons

\section{Recommended Citation}

Cass R. Sunstein, "Is There a Constitutional Right to Clone?" (Public Law \& Legal Theory Working Papers No. 22, 2002).

This Working Paper is brought to you for free and open access by the Working Papers at Chicago Unbound. It has been accepted for inclusion in Public Law and Legal Theory Working Papers by an authorized administrator of Chicago Unbound. For more information, please contact unbound@law.uchicago.edu. 


\title{
CHICAGO
}

Public LaW and Legal Theory Working Paper No. 22

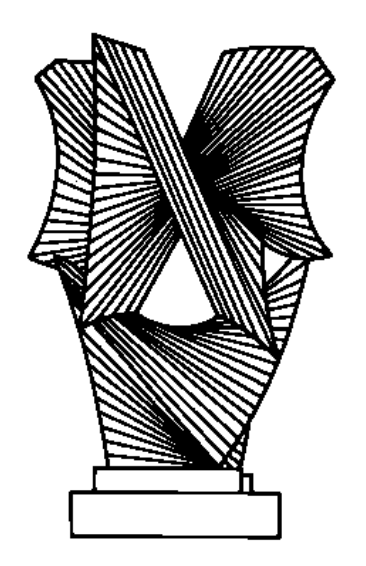

\section{Is There a Constitutional Right to Clone?}

\author{
Cass R. Sunstein
}

THE LAW SCHOOL

THE UNIVERSITY OF CHICAGO

This paper can be downloaded without charge at:

The Social Science Research Network Electronic Paper Collection:

http:/papers.ssrn.com/paper.taf?abstract_id=XXXXXX 
Preliminary draft $4 / 5 / 02$

All rights reserved

\title{
Is There a Constitutional Right to Clone?
}

\author{
Cass R. Sunstein ${ }^{*}$
}

\begin{abstract}
Recent scientific innovations, and proposed legislation, have raised questions about the nature of the constitutional right to reproductive freedom, and in particular about whether there is a constitutional "right to clone." This essay urges that as a matter of substantive due process, rationality review is probably appropriate, and that restrictions on both reproductive and therapeutic cloning would and should survive constitutional scrutiny. At the same time, many of the arguments for banning both forms of cloning are based on ignorance, myths, and speculation. It is extremely important to distinguish between reproductive and nonreproductive cloning, and it is equally important to distinguish among the various rationales for banning each. Some of those rationales have some, but others, including some of the most influential, are exceedingly weak.
\end{abstract}

As currently interpreted, the Constitution protects a range of rights involving marriage, bodily integrity, and reproduction. Does the Constitution guarantee the right to clone?

The question is not as fanciful as it might appear. ${ }^{1}$ Cloning is a possible method for "reproduction." For some people, cloning would undoubtedly be the preferred choice. Among this group, some would choose cloning on the ground that it is the only way to produce children with some genetic connection to them. For such people, the potential value of cloning should not be understated. And because reproduction is involved, the individual right to choose might well be thought to fall within the doctrinal protection given by Roe v. $\mathrm{Wade}^{2}$ and other cases. ${ }^{3}$ At the same time, it is not clear that the government can offer constitutionally adequate grounds for interfering with a presumptively protected right. Some of the most common justifications seem ignorant or speculative, and others could be taken care of through narrower means, falling short of a flat ban on cloning. Indeed, the justifications for banning cloning might well seem, at first glance, to be weaker than the justifications for banning abortion, which involves the intentional destruction of what many people consider innocent human life. If government cannot ban the intentional destruction of

\footnotetext{
* Karl N. Llewellyn Distinguished Service Professor of Jurisprudence, Law School and Department of Political Science, University of Chicago. This essay is a written version of the keynote luncheon address for the Hastings Law Journal symposium on human cloning, held in January 2002.

${ }^{1}$ See John Robertson, Liberty, Identity, and Human Cloning, 76 Tex. L. Rev. 1371, 1441-42 (1998).

${ }^{2} 410$ U.S. 113 (1973).

${ }^{3}$ See, e.g., Griswold v. Connecticut, 381 US 479 (1965); Eisenstadt v. Baird, 405 US 438 (1972); Carey v. Population Servs.. 431 US 113 (1973).
} 
human life, why -- it might be asked -- is government allowed to forbid the intentional creation of human life?

Notwithstanding these points, I will argue here that under existing law, there is no constitutional right to clone for reproductive purposes, and indeed that the argument for such a right is quite weak under the law as it now stands. I will also argue that there is no constitutional right to clone for therapeutic purposes, though the analysis must be quite different from that in the reproductive context. In the process of engaging the legal issues, I will offer a few more general remarks as well. Some of those remarks involve the appropriate judicial posture in cases involving "substantive due process." I will suggest that it is desirable for courts to be extremely cautious in extending the reach of cases that do not involve an element involving inequality or some other kind of failure from the democratic point of view. Judicial caution is justified in light of the complexity of the underlying scientific issues and the existence of a reasonable debate over the questions of policy and value. These are institutional points about the value of a general posture of judicial deference in a situation of this sort.

But some of my remarks bear on the general question whether government should, in principle, ban reproductive and therapeutic cloning. I do not mean to resolve those questions here, but I will suggest that many of the most commonly offered arguments are extremely weak, resting as they do on a mixture of ignorance and confusion. With respect to nonreproductive cloning, the argument for a presumptive constitutional right is strained under the precedents; but ironically, the government's justifications for intruding on freedom of choice are very weak indeed. Here as elsewhere, we should distinguish sharply between the legal question and the political question. The suggestion that there is no constitutional right to clone does not say whether a reasonable legislature would ban the practice of cloning; and here we shall see many reasons for doubt. At the very least, we should distinguish between the strongest justifications, now involving the doubtful safety of the procedure, and the weaker justifications, based on mistakes of fact or simple distaste.

\section{Reproductive Cloning: Is There a Presumptively Protected Right?}

For purposes of substantive due process, the first question is whether the right to clone counts as a fundamental right, one with which the government can interfere only to protect a "compelling" interest. If there is no fundamental right, the government is required merely to show a "rational basis" for its action, a much easier burden to meet. ${ }^{4}$ I begin with the use of cloning technology for purposes of reproduction.

\section{A. A Puzzling Pattern}

This is not the simplest question to answer. The reason is that that the Court has not-to say the least-given clear criteria for deciding when a right qualifies for special constitutional protection. The cases leave a great deal of ambiguity and the

\footnotetext{
${ }^{4}$ See, e.g., Williamson v. Lee Optical, 348 US 483 (1955).
} 
doctrine lacks much coherence. ${ }^{5}$ There are two common ways of reading the cases. One reading is that the Court has issued a firm "this far, and no more" and is unwilling to recognize additional fundamental rights unless they find specific and extremely strong recognition in Anglo-American traditions. This is the argument that Chief Justice Rehnquist appeared to accept for a majority of the Supreme Court in Washington v. Glucksberg. ${ }^{6}$ Of course this approach would not treat cloning as a presumptively protected right. The other reading is that the cases should be taken to establish a presumptive right to noninterference with decisions that are "highly personal and intimate," at least if those decisions involve choices about sexuality and reproduction. This approach might well require strong government justification of any interference with an individual decision to clone. I explore the two approaches in sequence.

\section{B. Due Process Traditionalism}

On occasion influential Justices and the Court as a whole have said that fundamental rights, under the due process clause, qualify as such largely because of their origins in Anglo-American traditions, understood at a level of considerable specificity. ${ }^{7}$ This was a theme of Chief Justice Rehnquist's opinion for the Court in Glucksberg, ${ }^{8}$ though Justice O'Connor's separate and narrower opinion draws its status into doubt. A central goal of due process traditionalism is to discipline judicial discretion and to draw on views that are time-honored and therefore unlikely to be idiosyncratic.

Let us for the moment assume that due process traditionalism is correct - that it describes the appropriate approach to the due process clause. If the right to clone must emerge from such traditions, the case is simple: There is no such right. The right to clone is not something that Anglo-American law traditionally protects. Of course we could say that the absence of a tradition of protection is not relevant, because the relevant technology is so new. But if such a tradition is a necessary condition for constitutional protection, there can be no right to clone.

At the same time, there are severe problems with defining fundamental interests solely by reference to tradition, specifically described. The first problem is that many of the Court's cases cannot be understood in purely traditionalist terms, and hence the traditionalist understanding of the privacy cases fits poorly with existing law. Roe v. Wade is the clearest example; there is no clear tradition establishing a right to abortion. But this is not true only of abortion. From the standpoint of tradition, a large number of the Court's cases make little sense. The cases establishing a right to contraceptives outside of marriage do not vindicate a longstanding tradition. ${ }^{9}$ Nor is

\footnotetext{
${ }^{5}$ See Bowers v. Hardwick, 478 U.S. 186 (1986)

6 521 U.S. 702 (1997).

${ }^{7}$ See Michael H. v. Gerald D., 491 U.S. 110, 127-28 n. 6 (1989) (plurality opinion of Scalia, J.); Bowers v. Hardwick, 478 U.S. 186 (1986); Moore v. City of East Cleveland, 431 U.S. 494 (1977) (plurality opinion of Powell, J.); Griswold v. Connecticut, 381 U.S. 479 (1965) (Harlan, J., concurring).

${ }^{8} 521$ U.S. 702, 710.

${ }^{9}$ See Eisenstadt v. Baird, 405 US 438 (1972); Carey v. Population Servs.. 431 US 113 (1973).
} 
there any general right to marry within Anglo-American traditions; hence Loving v. Virginia, ${ }^{10}$ striking down a ban on interracial marriage on due process clause, and Zablocki v. Redhail, ${ }^{11}$ recognizing a fundamental right to marry, fit poorly with due process traditionalism. Traditions, taken at a level of specificity and as brute facts, explain few of the key cases, and hence traditionalism does not make sense of existing law.

Should the Court consider its own decisions doubtful and use traditionalism in the future notwithstanding its inconsistency with past decisions? This course has considerable support within the Court; it is suggested by the Court's opinion in Washington v. Glucksberg, the plurality opinion in Michael H. v. Gerald D., and Bowers v. Hardwick.. And such a course might be deemed reasonable if traditionalism was extremely appealing in principle and if the alternatives were unacceptable. Perhaps a firm "no more!" would make sense despite its failure to fit with existing law; the Court's occasionally cavalier treatment of its own precedents implies a judgment of this sort. But if we assume that at least some kind of substantive due process is legitimate, ${ }^{12}$ as all of the Justices appear to assume, we will find large problems with using traditions, narrowly and specifically conceived, as the sole source of rights under the due process clause. To be sure, such a use of tradition does help to discipline judicial discretion, and that is an important gain. And if traditions were extremely reliable as sources of rights, and if judges thinking more independently about the appropriate content of rights were systematically unreliable, due process traditionalism might be justified on balance. That is, due process traditionalism might be justified as a way of minimizing the costs of decision and aggregate judicial errors even if it were quite imperfect as a source of rights.

But this is not a very plausible view, for there is no reason to think that traditions, understood at a level of great specificity, are systematically reliable or so close to systematically reliable as to exclude a somewhat more reflective and critical judicial role. ${ }^{13}$ Anglo-American traditions include a great deal of good but also significant confusion and injustice (consider, for example, bans on racial intermarriage); it is sensible for courts to engage in at least a degree of critical scrutiny of intrusions on liberty even if those intrusions do not offend tradition. Nor is there sufficient reason to think that judges will inevitably do very badly if they think critically about rights.

Of course judges should be very cautious about rejecting judgments made by elected officials; of course judges should avoid hubris in examining the past. Certainly it is plausible to think that judges should generally proceed incrementally and in good

\footnotetext{
10388 US 1 (1967).

11434 US 374 (1978)

12 Actually the whole idea of "substantive due process" is quite doubtful as a matter of text and history. But we might see that idea as doing the work of the privileges and immunities clause, which could plausibly have been used for an enterprise of this kind. See Charles Fairman, "Does the Fourteenth Amendment Incorporate the Bill of Rights?," 2 Stan. L. Rev. 5 (1949).

${ }^{13}$ I try to defend this view in Designing Democracy: What Constitutions Do (2001).
} 
common law fashion from previous decisions. It also makes sense to say that substantive due process should be used sparingly, because of its uncertain textual basis and because of the unreliability of judicial judgments about which rights should qualify as fundamental. Understandings of this kind provide important constraints on judicial power under the Due Process Clause. But at the very least it is appropriate for courts to ask whether the interest said to qualify as a fundamental right is, in principle, at all different from rights that have been sanctified by tradition. If, for example, there were no relevant difference, in principle, between a traditionally-unrecognized right to clone and (let us suppose) a traditionally-recognized right use contraceptives within marriage, courts should not say that the latter is constitutionally protected and the former is not.

\section{Reproduction and Sexuality}

If tradition is not decisive, what is the source of fundamental rights for purposes of substantive due process?

1. A False Start. It is tempting to resort to terms such as "intimate" and "personal"; but these terms provide little help. They tend to be conclusions masquerading as analytic devices. In any case, some of the cases deny protection to interests that seem highly intimate and highly personal; consider both $\underline{\text { Hardwick, }}{ }^{14}$ refusing to recognize a right to homosexual sodomy, and Village of Belle Terre v. Boraas, ${ }^{15}$ refusing a recognize an associational right to enable people to live together.. Thus the Court's cases refuse to accept the view that intimate and personal decisions deserve constitutional protection as such. Putting previous cases to one side, we can see that some decisions that seem intimate and personal are not strong candidates for constitutional protection. Consider the decision to work longer than the maximum hour laws allow in order to provide for one's family, the decision to take medicines or drugs of a certain sort, the decision to marry one's cousin or aunt, or for that matter the decision to commit suicide. There is good reason to think that the Constitution does not protect these decisions, however intimate and personal they seem. Thus a reference to "intimacy" or "personal" decisions is insufficiently unhelpful.

2. Reproduction and Sexuality. But the Court could find a narrower principle of some appeal, and considerable consistency with the cases, if it said that there is a presumptive right against government intrusions into the decision how and whether to produce children. This idea might be invoked to explain both Roe v. Wade and cases involving governmental efforts to prevent people from diminishing risks of pregnancy. The suggested standard also has the advantage of distinguishing Bowers v. Hardwick, the Georgia sodomy case, on the ground that there is no prohibition on the regulation of sexual conduct if decisions about pregnancy and childbirth are not involved. In any event, the standard seems to provide a sufficient if not necessary condition for constitutional concern. There do not appear to be any cases that fail to find a constitutionally protected interest in cases in which the standard is met.

${ }^{14} 478$ U.S. 186 (1986).

${ }^{15} 416$ US 1 (1974). 
3. Problems and Difficulties. It would not be frivolous to take the precedents in this way. ${ }^{16}$ But there are two problems with the argument.

The first is that it is not clear why the right to decide how and whether to produce children should have this special status, if other rights, such as the right to choose physician-assisted suicide and the right to engage in consensual sexual activities, do not. Surely it is true that decisions about reproduction -- about whether and how to reproduce -- are central to individual autonomy. But many other decisions seem equally central, or at least not less central, and those decisions do not receive special constitutional protection. Why should reproduction be singled out? The question suggests that the cases involving reproduction and contraception may not, in fact, only involve those issues, and that they may be marked by another feature, one that involves sex equality. Perhaps issues of that kind also helped motivate the Court. A ban on abortion has disproportionate effects on women, to say the least; and when a law forbids the use of contraceptives, women are likely to face especially strong adverse effects, in the form of an involuntary pregnancy. Indeed, several members of the Court has acknowledged that Roe v. Wade owes something to equality concerns, ${ }^{17}$ and it does seem clear that bans on contraception have disproportionate effects on women.

This equality concern does not appear to be present with bans on cloning. Do such bans treat women as such worse than men? Do such bans treat any disadvantaged group especially badly? To be sure, it would be possible to urge that people who are disabled, in the sense that they lack the ability to produce children in the standard fashion, are distinctly harmed by bans on cloning. But whenever the government imposes barriers to use of some medicine or medical technology, there is a disproportionate burden on those who believe that they need it. By itself that burden is not enough to create a serious constitutional issue.

The second problem in the argument is that it defines the relevant interests very broadly, and in a way that is not at all compelled by the cases. People might have a right to decide whether to abort, and whether to use contraceptives, without also having a right to choose any available means to have, or not to have, a child - even if that means is, for some people, the only realistic means. We should agree that it would be presumptively unacceptable for the government to ban certain couples from having children, or to impose a one-child policy on the nation. We should also agree that the government may not require people to have children, and indeed that government may not bar women from availing themselves of what is, for most people, the usually indispensable means of preventing the birth of unwanted children (such as contraception and abortion). But none of this means that there is a presumptive right to do whatever might be done to increase the likelihood of having, or not having, a child: to enter into surrogacy arrangements, or to use in vitro fertilization, or to attempt to clone a child. The central point is that a ban on cloning, or on surrogacy arrangements,

\footnotetext{
${ }^{16}$ As the district court seemed to in Lifchez v. Hartgan, 735 F. Supp. 1365 (N.D. Ill. 1990), affirmed without opinion sub nom. Scholberg v. Lifchez, 914 F.2d 260 ( $7^{\text {th }}$ Cir. 1990).

${ }^{17}$ See Planned Parenthood v. Casey, 505 U.S. 933 (1992).
} 
leaves open numerous other channels by which most people may bear a child. If numerous channels remain open, perhaps the government need not face the strongest possible burden when it merely closes off one.

The point should not be overstated. There are many means to prevent unwanted childbirth (I omit the details); abortion and contraception are hardly the only methods. And for some people, cloning might be the only feasible way to produce a biological offspring. For imaginable plaintiffs in an imaginable case, a ban on cloning is effectively a ban on reproduction in the biological sense. It would certainly not be ludicrous to say that as a matter of constitutional law, the state has to produce a strong justification for intruding on that choice in cases in which it is the only realistic option. Indeed there is reason to question a doctrine that would apply strict scrutiny to a ban on "natural" reproductive practices while applying only deferential review to a ban on new technologies. But where there is no problem of inequality, courts would probably not, and should probably not, demand the kind of overwhelming justification that is required in some cases. Indeed it seems sensible to understand the Court's precedents as reflecting special circumstances: the potentially large intrusion on women's bodies that is entailed by a ban on abortion or contraception, and the fact that when such bans are in place, women's equality is at risk.

\section{Reproductive Cloning: State Justifications}

I now turn to the arguments that might be offered to justify a ban on reproductive cloning. These arguments can be taken in two ways. First, they might be an effort to show that the government has a rational basis for the ban - all that is required if, as I believe, a fundamental right is not involved. Second, they might be invoked to show that government has a compelling interest in banning reproductive cloning - the showing that is required under strict scrutiny. My basic conclusion is that most of the arguments, and perhaps even all of them, are sufficient to satisfy rational basis review. I also urge that if a compelling interest must be shown, the most stringent standard is met by the significant risk that cloning would result in a greater deal of illness, suffering, and death.

\section{A. Three Weak Arguments}

1. Moral Repugnance. In a widely discussed essay, Leon Kass has pointed to what he calls the "wisdom" of repugnance, and urged that disgust or repugnance is by itself a sufficient reason to ban a practice. ${ }^{18}$ There is an interesting claim in the background here. Perhaps repugnance, even of the visceral sort, reflects a kind of wisdom and rationality that are superior to readily accessible arguments. Is moral repugnance, felt by many people, enough to meet the government's burden?

\footnotetext{
${ }^{18}$ See Leon Kass, The Wisdom in Repugnance, in Leon Kass and James Q. Wilson, Cloning: For and Against 1998).
} 
The Supreme Court has indicated that it is, at least in the context of a prohibition of homosexual sodomy. ${ }^{19}$ And undoubtedly it is true that "disgust" sometimes captures a sound moral intuition, and that on reflection, we will find that moral repugnance is based on good grounds. Sometimes repugnance is fully rational. But standing by itself, and not subject to reason or scrutiny, moral repugnance seems to be a weak basis for intruding on a human choice. Moral repugnance has been invoked for many bans that could not easily withstand analysis; consider bans on racial intermarriage or masturbation. In the context of cloning, moral repugnance might well be a response to vaguely remembered science fiction stories or horror movies, or to perceptions based on ignorance and confusion (as in the idea that a clone is a complete "copy" of the original, or a "copy" that is going to be evil). The real task is to see if moral repugnance can be defended, not simply asserted.

But these points remain to be translated into constitutional terms. If we are speaking of strict scrutiny, moral repugnance by itself cannot be sufficient; Loving v. Virginia $^{20}$ is enough to establish the point. Moral repugnance must be explained, not merely asserted. If rational basis review is at work, and if the task is merely to describe current law, moral repugnance does seem adequate under the authority of Bowsher v. Hardwick. But there is every reason to be uneasy with this conclusion. Indeed, in the context of discrimination against the mentally retarded, offense and repugnance were expressly found to be irrational and hence constitutionally inadequate. ${ }^{21}$ To uphold a ban on reproductive cloning, we should seek some other rationale, even under the rational basis test.

2. Lessening the Worth of Individuals and Threatening Individuality. Would cloning lesson the worth of individuals? Would it make the clone less of an individual? The person whose genetic materials were used? Would it diminish the uniqueness of human identity? Some people appear to think so. No less an authority than Ian Wilmut has said, "I think that each child should be treated as an individual; and if you have chosen to make a child, who is a copy of someone who is already here, you can't possibly treat that person as an individual." 22 My speculation is that for many people, the idea of "copying" human beings is unacceptable, simply because of what it seems to do to the individuals involved.

Here too, however, the argument seems to dissolve on reflection. Wilmut is making an empirical claim ("you can't possibly treat that person as an individual"), and taken as such, the claim is very weak. Identical twins are genetically identical, and the existence of identical twins does not lesson the worth of individuals, or make anyone less of an individual. If John and Jim are genetically the same, they are likely to be similar in many ways for that very reason; but they will not be identical, simply because they will have different experiences, and experiences affect personality and development. It is not necessary to set out controversial claims about the precise mix of

\footnotetext{
${ }^{19}$ See Bowers v. Hardwick, 478 U.S. 186 (1986).

20388 US 1 (1967).

${ }^{21}$ Cleburne v. Cleburne Living Center, 473 US 432 (1985).

${ }^{22}$ CNN Larry King Live (CNN television broadcast, June 24, 1997).
} 
genetic endowments and environment in order to make the point. The individuality of the person whose DNA is used to create a clone would not be compromised by the fact; nor would the individuality of the clone be affected as a result. ${ }^{23}$ Indeed, the difference between cloning and ordinary reproduction should not be overstated on this count. Many children are extremely close, as a genetic matter, to one or another parent.

If we are speaking of strict scrutiny, a ban on cloning cannot plausibly be defended on this ground. Simply because rational basis review is so deferential, the argument from individuality might be sufficient to support a ban. But even here, the argument is extremely shaky.

3. Genetic Diversity. A species does well if it has a large stock of genetic diversity. Some people who are concerned about human cloning fear that if it occurs, the stock will be diminished - making the world, or parts of it, a bit like the English royal family. If this is a plausible threat, wouldn't it be legitimate for a state or a nation to ban cloning for that reason alone?

On reflection, this too is an extremely weak argument, certainly insufficient to satisfy strict scrutiny, and probably insufficient to satisfy rational basis review. The reason is that it defies belief to suggest that cloning would become so popular as to reduce, in any significant way, the existing level of genetic diversity.

\section{B. Three Stronger Arguments}

1. Protecting against Suffering and Early Death. The first and simplest justification is that in light of the current state of medical technology, it is highly likely that cloned human beings would face serious medical problems -- leading, in many cases, to serious illness and early death. ${ }^{24}$ The underlying risks include high rates of miscarriage, deformed children, premature aging, and high rates of cancer and other diseases. ${ }^{25}$ There are possible risks to the mother as well. ${ }^{26}$

Let us assume that this pessimistic account of the current situation is accurate as a scientific matter. If it is true, it should be easily sufficient to satisfy rational basis review. Indeed, it is probably sufficient to satisfy even the most stringent standard of review, though under that standard, the scientific claims will be investigated closely. If the claims are taken to be adequate - as prominent groups have concluded ${ }^{27}-$ then a ban is likely to be upheld even if the consequence is to prevent the development of technology that would reduce the relevant risks. By hypothesis, the practice of cloning would lead to much suffering and many deaths. The government would seem to have strong reason to prevent that practice. Compare the question of animal welfare. If

\footnotetext{
${ }^{23}$ Below I address some psychological complications.

${ }^{24}$ See Report of the California Advisory Committee on Human Cloning, Cloning Californians? (Jan. 11, 2002); Report of the National Academy of Sciences (2002).

${ }^{25}$ See id; see also Robertson, supra note, at 1411.

${ }^{26}$ See Report of the California Advisory Committee, supra note, at 23-24.

${ }^{27}$ See id.
} 
scientists are experimenting with animals in a way that will lead to a great deal of suffering, the government is certainly allowed to intervene, even if the experiments would have many benefits too.

There is, however, a possible counterargument. Roe v. Wade held that the interest in protecting fetal life is not sufficient to override the right of privacy. Suppose that many or most of the early deaths would involve fetuses, not viable human beings. Is it not clear, after Roe, that the interest in protecting fetal life cannot overcome the right to choose? The simplest answer is that strict scrutiny is likely not to be involved, and hence the interest in protecting fetal life is indeed sufficient. A slightly less simple answer is that in light of current technology, a ban on cloning would protect fetuses, young children, and mothers themselves, and hence the question turns out to be easy. If we are speaking of strict scrutiny, the best answer is that a ban on cloning is justified as an effort to protect not only fetuses, but also people who are actually born. Even if a relatively small percentage of clones (10\%? 20\%?) would suffer in the predicted way, the state almost certainly has sufficient reason, as a constitutional matter, to ban the practice.

2. Psychological Harm to the Clone. It is possible to urge that the clone would suffer psychological harm, even psychological trauma. Imagine the likely emotional state of someone who knows that he or she is genetically identical to someone who has already lived a number of years. Perhaps such a person would believe that her future course was in many ways preordained - that some possibilities were open and others were closed off. If the clone's genetic equivalent suffered from high blood pressure, or diabetes, or cancer, she might believe, with very good reason, that she would face those problems as well. Other problems are more subtle. If the genetically identical parent faced a depressing career path, or had unappealing physical features or an unpleasant smile or laugh, or was badly overweight, it might prove difficult - far worse than distressing - for the clone.

These are plausible concerns, though they do involve a degree of speculation. We do not know whether in most or many cases, the psychological harms would be serious. Identical twins appear to do very well notwithstanding the fact that psychological harm could be predicted. To be sure, the case of human cloning would be different, simply because of the age difference between the people involved; the harms I am discussing would be a product of seeing a life that has run much of its course. But biology is not (entirely) destiny, and we could easily imagine young people concluding that even if they are genetically equivalent to one or another parent, or some other living person, their path is hardly foreordained. Is cloning so radically different, on this count, from ordinary reproduction? I am not sure.

As far as the Constitution is concerned, however, the issue will be resolved by selection of the governing standard. If the rational basis test is involved, the arguments from psychological harm are undoubtedly sufficient. If strict scrutiny is the appropriate standard, the speculative nature of the argument is probably decisive, and the ban could not be defended on this ground alone. 
3. Use and Exploitation of Human Beings. Of the stronger arguments for banning reproductive cloning, the third is the most interesting. Imagine a situation in which cloning was freely permitted - in which individuals could clone themselves, and in which people interested in children with a certain genetic endowment could assure themselves of that very endowment. If a family wanted a terrific athlete, it could obtain a genetic equivalent of, say, Michael Jordan; if it wanted a terrific musician, it could obtain a genetic equivalent of, say, Bob Dylan; if it wanted a terrific scientist, it could obtain a genetic equivalent of, say, Ian Wilmut; if it wanted a terrific philosopher, it could clone John Rawls. Why would this be objectionable? The reason is that people would be treating their children-to-be as means, with prearranged agendas, rather than as ends, to seek their own path. Someone who seeks a clone of Michael Jordan might well have a particular plan in mind for that individual. So too with anyone who has sought, and been able, to choose people with one or another genetic endowment. In such cases, the parents would be carefully programming their children's future, and likely, perhaps, to keep the program in mind throughout childhood.

Of course this is not altogether different from ordinary life. Many parents have particular plans for their children. Many parents are insistent on those plans. Sperm and egg donations depend, in part, on perceptions about genetic endowments. But the particular programming that I am now discussing cannot be achieved. Perhaps parents who produce clones will, too much of the time, treat their own children not as ends but as means. ${ }^{28}$ If we see a significant increase in that kind of treatment, there would seem to be considerable reason for concern.

Is this an adequate justification, by itself, for banning cloning? If the rational basis test is at work, it certainly is; and for reasons suggested above, rational basis should be all that should be required here. But if we probe a bit more deeply, we will uncover some complexities. The argument depends on a speculation about what people would do, and we do not know if the speculation can be supported. Perhaps most people would clone themselves, or would seek clones of strangers who meet some genetic minimum, and would not attempt to clone particular individuals with particular traits and career paths. Perhaps this would be rare. Probably those who cloned people with particular characteristics would, almost all of the time, treat their children with love and respect. Here as elsewhere, strict scrutiny is not easy to satisfy, and here as elsewhere, a widespread argument against human cloning seems to rest on weak grounds.

\section{Therapeutic Cloning}

Therapeutic cloning presents quite different issues. ${ }^{29}$ Here there is no effort to create actual human beings. Children are not involved. My basic conclusion is that it is not at all easy to argue that there is a fundamental right to engage in therapeutic cloning - indeed, the argument for that right is weaker, as a legal matter, than the argument for a right to engage in reproductive cloning. On the other hand, the

\footnotetext{
${ }^{28}$ Robertson, supra note, at 1418.

${ }^{29}$ As recognized in national and California reports on the point. See note 24 supra.
} 
justifications for banning therapeutic cloning are relatively weak - much weaker, in fact, than the strongest justifications for banning reproductive cloning. To understand the constitutional issues associated with a ban on therapeutic cloning, a brief background is in order.

\section{A. A (Very) Little Science}

Here, in brief, is how therapeutic cloning would work. An embryo would be created and allowed to grow for a short period, perhaps fourteen days or less. Its stem cells would then be extracted and grown into human issue or a complete human organ for transplant. The result of the process would not be a human being, but a piece of nerve tissue, or a replacement organ, or a certain amount of skin. The goal would be to grow replacement organs from a sample of someone's DNA.

It is not clear if and when therapeutic cloning will succeed, but the potential benefits are large. In theory, people could receive perfectly matched replacement organs, with little or no danger of rejection of the transplant. Insulin-secreting cells could be used to treat diabetes; nerve cells could be used for Parkinson's disease or strokes; liver cells could be used to repair damaged organs. There would be no need to wait for the death of a donor. Nonreproductive cloning could also produce significant benefits for knowledge and research, with eventual medical advances as well.

\section{B. No Fundamental Right}

Is there a fundamental right to engage in therapeutic cloning? The issue is quite different from the case of reproductive cloning, for childbirth is not in any sense involved. Hence the precedents that might support a right to reproductive cloning cannot be invoked here. For constitutional purposes, the central question is whether there is a presumptive right to select medical treatments. Those who seek to engage in therapeutic cloning might be protected if the Constitution recognizes such a presumptive right. We can imagine patients, or derivatively scientists and researchers, urging that the right to privacy includes a presumptive right to noninterference with choices among medical treatments that are crucial to people's well-being.

At first glance, however, the mere statement of the question serves as an answer. No Supreme Court decision suggests that there is any such right. Indeed, daily practice argues against its existence. The Food and Drug Administration controls the kinds of medicines that doctors may prescribe and that patients may choose. It would be fanciful to attack those controls on constitutional grounds. Now perhaps it could be urged that in the relevant cases, the FDA is attempting to protect people against fraud or deception, or against the effects of their own ignorance, and that these are not the grounds for forbidding nonreproductive cloning. Probably this is true. But the key point is that the FDA is not required to justify its decisions in the terms of strict scrutiny, on pain of constitutional invalidation. 
We have seen that it is not implausible to argue, on the strength of Roe v. Wade, that the government would be required to produce a strong justification for any effort to ban in vitro fertilization or surrogacy arrangements. But nothing in Roe v. Wade supports to right to choose medical treatments. Recall that the Court has upheld a ban on physician-assisted suicide, applying rational basis review. ${ }^{30}$ If people do not have a right to choose death, it is unlikely that they have a right to a particular set of medical experiments that might ultimately benefit them. Or consider another analogy: scientific experiments on animals. Must the government justify a limitation on such experiments in the terms of strict scrutiny, simply because important medical advances might result? This is most doubtful. No court has ever suggested that strict scrutiny will apply to government efforts to protect animals in the process of experimentation.

I do not mean to suggest that the area lacks complexities. Perhaps it could be argued that while there is no right to die, there is a right to live, and that when a patient seeks to use medical technology that is the (only) means of saving his life, that the government should be required to produce an unusually convincing justification. This is not entirely implausible. But it would go well beyond the existing precedents, and it would also have the disadvantage of requiring careful judicial oversight of numerous decisions by the FDA. One of my general themes has been the value of judicial deference, under the due process clause, in the face of complex disputes of fact and value. A posture of deference makes best sense here as elsewhere. ${ }^{31}$

\section{Elusive Justifications}

What interests support a ban on therapeutic cloning? The answer is not simple. Those who object to therapeutic cloning tend to believe that personhood begins at conception, and that the state should not use "persons" for the benefit of others. Is this an adequate justification? In the case of rational basis review?

It might be tempting to say that this justification is inadequate after Roe $\mathrm{v}$.

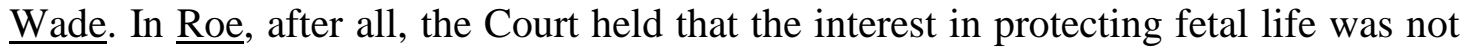
sufficient to justify a ban on cloning. But the temptation should be resisted. Roe holds only that the interest in protecting fetal life is inadequate to override the woman's right to choose; it does not hold that the interest is illegitimate or weightless. It seems clear that government can make it a crime to kill first-trimester fetuses, whether they are inside women's wombs or in the laboratory; and to justify such a prohibition, it is not necessary for government to say that first-trimester fetuses are human beings.

But what is the reason for forbidding nonreproductive cloning? Those who object to therapeutic cloning may be unsure whether personhood begins at conception, but may nonetheless press two points. First, they may think that the use of human pre-embryos is itself a moral wrong. Second, they may urge that the use of human embryos could tend to have subtle but ultimately corrosive effects on human

\footnotetext{
${ }^{30}$ Washington v. Glucksberg, 521 U.S. 702 (1997).

${ }^{31}$ I do not discuss the question whether there is a first amendment right to engage in medical or scientific research. The law is ill-developed on this point.
} 
values, in a way that will lead to an assortment of problems. If rational basis review is at work, these points should be sufficient to support the ban as a matter of constitutional law. I do not mean to endorse the claims in principle. Why is it a moral wrong to use pre-embryos in the suggested way? Animals are frequently used as means; most of these uses are lawful; and at least some of them seem morally acceptable. Do pre-embryos have such a strong claim to protection? Or consider the view that human values will be corroded by nonreproductive cloning. Why, exactly, should this be feared, if nonreproductive cloning is not itself morally wrong for the purposes and in the circumstances I am describing? The empirical claim seems most doubtful.

Perhaps the real argument is that early embryos have the "potential" to become human beings, and are worthy of moral concern for that reason. ${ }^{32}$ But this argument seems weak too. Sperm cells have "potential," and (not to put a fine point on it) most people are not especially solicitous about them. If scientists will be using and cloning embryos only at a very early stage when they are just a handful of cells (say, before they are four days old), there appears to be no good reason for a ban.

Perhaps the strongest ground for banning nonreproductive cloning has nothing to do with these points. Perhaps it is a different sort of empirical claim, to the effect that a ban on nonreproductive cloning is a necessary means for enforcing the ban on reproductive cloning. It might be feared that if nonreproductive cloning is permitted, some people, at some point, will inevitably use the pre-embryos in the forbidden way, so as to produce, or to try to produce, children. Here too there are many doubts. If reproductive cloning is a crime, should we really fear that nonreproductive cloning would be used for that by hypothesis unlawful end? But if rational basis review is at work, this justification should be sufficient.

\section{Concluding Remarks on Cloning and Substantive Due Process}

This has been a lawyer's essay, exploring the constitutional issue, not the question of policy. I have argued that bans on cloning are constitutional, not that they are a good idea.

With respect to substantive due process, I have offered a general claim. The Court should be most reluctant to invoke the due process clause to strike down legislation on substantive grounds. Where the Court has acted, it has usually done so because of an implicit understanding that the case did not simply involve substantive due process. In cases involving sexuality and reproduction, a question of sex equality was also involved. The argument for a cautious approach to the due process clause depends in part on a belief that the idea of "substantive due process" is awkward as a matter of text and history. But it also depends on a belief in judicial fallibility, especially in the domain of complex facts and contested values. Simply because of its complexity, the area of cloning is a prime arena for judicial deference. Unless there is some problem in the process that led to the law under review, courts should be hesitant

${ }^{32}$ As argued I Francis Fukuyama, Our Posthuman Future (2002). 
to interpose their own views, at least outside of the most egregious cases. Tradition is indeed relevant here, at least as a way of undertaking the inquiry into egregiousness; an unprecedented intrusion is likely to be especially egregious. Tradition does not exhaust the substantive content of the due process clause. But the intrusion marked by bans on cloning does not rise to the level of intrusions the Court has marked for invalidation; and that is sufficient for my basic conclusion here.

I have argued that there is no constitutional right to clone human beings for reproductive purposes, and hence a ban on cloning, for those purposes, would and should be upheld. I have also argued that there is no constitutional right to clone human beings for therapeutic purposes. In both cases, the Constitution does not create a presumptively protected right -- and hence the government is not required to show more than a rational justification for its actions. In both cases, the government has such a justification. In the case of reproductive cloning, the best argument is the least sectarian - that a ban is necessary to protect against human suffering. In the case of therapeutic cloning, a ban is far harder to justify. But so long as rationality review is at work, it is probably sufficient to say that the ban on therapeutic cloning is a means of making the ban on reproductive cloning effective.

At the same time, the analysis has shown that many of the standard objections to human cloning are extremely weak. Some of those objections depend on ignorance and confusion, or on a kind of half-remembered message from old science fiction movies. By itself, repugnance should not be, in principle, an adequate justification for law. An unintended byproduct of a discussion of the constitutional issue may be to take some small steps toward something that is long overdue and much needed in the political arena: A disaggregation of the issues that are involved in reproductive and nonreproductive cloning, and a separation of the diverse, sometimes strong, but sometimes implausible grounds that are invoked on behalf of statutory bans in both domains.

Readers with comments should address them to:

Cass R. Sunstein

University of Chicago Law School

1111 East 60th Street

Chicago, IL 60637

csunstei@midway.uchicago.edu 


\section{University of Chicago Law School}

\section{Public Law and Legal Theory Working Paper Series}

1. Cass R. Sunstein and Edna Ullmann-Margalit, Second-Order Decisions (November 1999; Ethics, v. 110, no. 1).

2. Joseph Isenbergh, Impeachment and Presidential Immunity from Judicial Process (November 1999; forthcoming Yale Law and Policy Review v.18 \#1).

3. Cass R. Sunstein, Is the Clean Air Act Unconstitutional? (August 1999; Michigan Law Review \#3).

4. Elizabeth Garrett, The Law and Economics of "Informed Voter" Ballot Notations (November 1999, University of Virginia Law Review, v. 85).

5. David A. Strauss, Do Constitutional Amendments Matter? (November 1999)

6. Cass R. Sunstein, Standing for Animals (November 1999)

7. Cass R. Sunstein, Culture and Government Money: A Guide for the Perplexed (April 2000).

8. Emily Buss, Without Peers? The Blind Spot in the Debate over How to Allocate Educational Control between Parent and State (April 2000).

9. David A. Strauss, Common Law, Common Ground, and Jefferson's Principle (June 2000).

10. Curtis A. Bradley and Jack L. Goldsmith, Treaties, Human Rights, and Conditional Consent (May 2000; Pennsylvania Law Review v. 149).

11. Mary Ann Case, Lessons for the Future of Affirmative Action from the Past of the Religion Clauses? (May 2001, Supreme Court Review, 2000)

12. Cass R. Sunstein, Social and Economic Rights? Lessons from South Africa (May, 2000).

13. Jill Elaine Hasday, Parenthood Divided: A Legal History of the Bifurcated Law of Parental Relations

14. Elizabeth Garrett, Institutional Lessons from the 2000 Presidential Election (May 2001).

15. Richard A. Epstein, The Allocation of the Commons: Parking and Stopping on the Commons (August 2001).

16. Jack Goldsmith, The Internet and the Legitimacy of Remote Cross-Border Searches (October 2001).

17. Adrian Vermeule, Does Commerce Clause Review Have Perverse Effects? (October 2001).

18. Cass R. Sunstein, Of Artificial Intelligence and Legal Reasoning (November 2001).

19. Elizabeth Garrett, The Future of Campaign Finance Reform Laws in the Courts and in Congress, The William J. Brennan Lecture in Constitutional Law (December 2001).

20. Julie Roin, Taxation without Coordination (March 2002).

21. Geoffrey R. Stone, Above the Law: Research Methods, Ethics, and the Law of Privilege (March 2002; forthcoming J. Sociological Methodology 2002).

22. Cass R. Sunstein, Is There a Constitutional Right to Clone? (March 2002). 